\title{
Analisis Gerak Lokomotor Dalam Permainan Tradisional Dalam Permainan Hadang Kelas B1 Usia 5-6 Tahun Di PAUD Negeri Pembina 1 Kota Ternate
}

\author{
Nur Wulan Machmud, ${ }^{1}$ Farida Samad, ${ }^{2}$ Rita Samad, ${ }^{3}$ Fatoni Achmad,4 \\ Universitas Khairun Ternate \\ Jl. Bandara Baabullah Kampus 1 Unkhair, Kelurahan Akehuda Kota Ternate Kode Pos 97728 \\ Email: Nurwulanmachmud @gmail.com
}

\begin{abstract}
Abstrak: Penelitian ini bertujuan untuk mendeskripsikan gerak lokomotor dalam permainan tradisional Hadang pada siswa Kelompok B1 PAUD Negeri Pembina 1 Kota Ternate. Jenis penelitian ini adalah penelitian kualitatif. Subjek penelitian ini adalah 4 siswa kelompok B1 di PAUD Negeri Pembina 1 kota Ternate. Teknik pengumpulan data yang digunakan adalah observasi, dokumentasi dan wawancara dengan 2 orang guru. Analisis data penelitian yang digunakan adalah teknik analisis kualitatif yang terdiri dari pengumpulan data, reduksi data dan verifikasi/kesimpulan data. Penelitian ini memiliki 1 variabel yaitu gerak lokomotor dalam permainan halangan yang di dalamnya terdapat indikator sebagai berikut: 1) berpindah tempat. 2) berlari dan 3) melompat. Hasil penelitian menunjukkan bahwa terdapat gerak lokomotor dalam permainan tradisional Hadang yang dimainkan oleh siswa di PAUD Negeri Pembina 1 Kota Ternate. Berdasarkan hasil analisis yang dilakukan peneliti gerak lokomotor pada permainan tradisional Hadang yang dimainkan siswa di PAUD Negeri Pembina 1 Kota Ternate berkembang dengan sangat baik, hal ini dibuktikan dengan hasil observasi langsung oleh peneliti yang menunjukkan bahwa 4 siswa dapat memainkan permainan blokade dan melakukan gerakan lokomotor dengan sangat baik. Pengembangan gerak lokomotor yang baik pada anak usia dini dapat dilakukan dengan mengadakan program pengembangan permainan tradisional karena tidak hanya baik untuk anakanak tetapi juga dapat ikut melestarikan permainan tradisional yang jarang dimainkan oleh anakanak saat ini.
\end{abstract}

Kata kunci: Gerakan Lokomotor, Permainan Tradisional Hadang, Anak

Abstract: This research aims to describe locomotor motion in the traditional game of Block in Group B1 PAUD Negeri Pembina 1 Ternate City students. This type of research is qualitative research. The research subjects were 4 students of group B1 in PAUD Negeri Pembina 1 Ternate city. Data collection techniques used were observation, documentation and interviews with 2 teachers. Analysis of the research data used is a qualitative analysis technique which consists of data collection, data reduction and data verification/conclusion. This study has 1 variable, namely locomotor motion in the hitch game in which there are the following indicators: 1) changing places. 2) running and 3) jumping. The results showed that there was locomotor movement in the traditional game of Block played by students at PAUD Negeri Pembina 1 Ternate City. Based on the results of the analysis conducted by researchers of locomotor motion in the traditional game of Block played by students at PAUD Negeri Pembina 1 Ternate City is developing very well, this is evidenced by the results of direct observations by researchers who show that 4 students can play the blockade game and perform locomotor movements very well. The development of good locomotor motion in early childhood can be done by holding a traditional game development program because it is not only good for children's but can also participate in preserving traditional games that are rarely played by children today.

Keywords: Locomotor Movement, Traditional Game Of Block, Children 


\section{A. Pendahuluan}

Pendidikan anak usia dini sangat penting karena pada masa ini sering sebagai the golden age, Seperti yang diungkapkan dan masa the golden age adalah masa-masa keemasan seorang anak, yaitu masa ketika anak mempunyai banyak potensi yang sangat baik untuk dikembangkan. Jangan sampai di masa ini anak perkembangannya terganggu karena pada usia dini anak banyak memperoleh pengetahuan dasar.

Anak usia dini tidak hanya mengalami perkembangan tetapi juga memiliki karakteristik yang unik, anak usia dini memiliki karakter dasar yaitu bekal kebaikan disini maksudnya adalah anak usia dini sejak lahir sudah memiliki kebaikan, oleh karena itu dalam perkembangannya harus dibiasakan pada hal-hal yang baik. Anak usia dini suka meniru terutama gerakan atau perilaku orang tua atau lingkungan di dekatnya. Apa yang anak lihat dan rasakan akan selalu di ikutinya. Karakteristik anak yang lain adalah suka bermain.Tidak dapat dipungkiri bahwa anak usia dini sangat menyukai bermain karena sifatnya menyenangkan dan mengasyikkan. Selain itu, anak usia dini juga memiliki rasa ingin tau yang tinggi.

Perkembangan kinestik anak usia dini adalah kemampuan yang berhubungan dengan kelancaran gerak tangan atau keterampilan fisik motorik anak usia dini. Tujuan dari pengembangan ini adalah mengkoordinasikan keseimbangan, kekuatan dan kelunturan otot-otot anak usia dini, anak yang memiliki kecerdasan kinestik memiliki kordinasi tubuh yang baik. Gerakan-gerakan mereka terlihat simbangan, luwes, cekatan, cepat menguasai tugas-tugas motorik halus seperti menggunting, menulis, melipat, menjahit dan menepel.

Kemampuan motorik, terutama kemampuan motorik kasar, sangatlah penting. Penguasaha kemampuan motorik ini wajib dimiliki oleh anak sebagai dasar untuk menguasai gerak selanjutnya yang lebih kompleks dan berguna untuk meningkatkan kualitas hidup anak di masa akan datang. Dengan matangnya kemampuan motorik pada anak, maka anak tidak akan merasa kaku dalam menggerakan kaki dan tangannya. Dalam motorik anak terlihat seberapa jauh anak tersebut mampu menampilkan tugas motorik yang diberikan dengan tingkat keberhasilan tertentu.Jika tingkat keberhasilan dalam melaksanakan tugas motorik tinggi, berarti motori yang dilakukannya efektif dan efisien.

Seperti telah diketahui, perkembangan motorik terbagi ke dalam bagian, yaitu perkembangan motorik kasar dan motorik halus. Hal tersebut di kemukakan" dua macam keterampilan motorik yaitu keterampilan koordinasi otot halus dan keterampilan otot kasar" Keterampilan koordinasi otot halus biasanya dipergunakan dalam kegiatan belajar di dalam ruangan, sedangkan keterampilan otot kasar dipergunakan diluar ruangan. Senada dengan mengatakan "pengayangan motorik terdiri dari motorik halus dan motorik kasar", Motorik halus adalah kemampuan anak beraktivita dengan menggunakan otot-otot halus, seperti menulis, meremas, menggengam, dan memasukan kelereng. Sedangkan motorik kasar adalah kemampuan anak beraktivitas menggunakan otot-otot besarnya yang mana tergolong pada kemampuan gerak dasar yang dibagi menjadi 3 kategori yitu lokomotor, lokomotor dan manipulatif.

Berdasarkan hasil observasi dan wawancara guru hasil pemahaman bahwa dalam permainan tradisional hadang ini dapat menstimulasikan serta mengembangkan kemampuan motorikdalam permainan tradisonal, di PAUD Negeri Pembina 1 Kota 
Ternate masih terbilang sudah cukup optimal. Hal tersebut hasil wawancara dengan guru yang di lakukan pada tanggal 19 Februari 2021 mendapati bahwa di sekolah di PAUD Negeri Pembina 1Kota Ternate ada beberapa jumlah anak di kelas B1ada 25 peserta didik. Jadi yang saya obervasi untuk kegiatan permainan hadang ini hanya untuk fokus pada kelas B1 dalam permainan hadang. Dari sekian banyak anak ada beberapa anak perkembangan motorik belum optimal, karena pada saat pembelajaran anak melakukan permaianan yaitu permaianan hadang dimana permaianan ini di bagi menjadi dua regu masing-masing 5 orang dan 3 orang cadangan. Pada saat observasi peneliti ini menemukan beberapa anak gerak lokomotor belum optimal. Beberapa anak ada yang masih bingung dalam permainan tersebut ada juga anak yang aktif dalam permainan ini anak masih sangat kurang mampu untuk menangkap sasaran ke tepat sasaran atau musuh masih kurang baik ada pun juga anak yang sudah mulai berkembang dalam permaianan hadang, hadang ini mengunakan alat yang di pakai adalah lak band dan menggunakan sebuah ruangan yang luas.

Di dalam permainan hadang ini terdapat kegiatan melatih motorik anak, menangkap lawan musuhnya. Kegiatan-kegiatan tersebut adalah salah satu aspek perkembangan motorik anak usia dini. Maka dari itu, permaianan hadang ini diharapkan mampu mengembangkan anak usia dini. Karena bermain permainan hadang ini, dalam menjaga lawananya, dan menangkap akan dilatih dan dilakukan secara beruang-ulang saat permainan berlangsung.Maka penulis tertarik untuk mencoba menganalisis permasalahan dengan topik penelitan sebagai berikut: "Anaisis Gerak Lokomotor dalam permainan tradisional Hadang di PAUD Negeri Pembina 1 kota Ternate".

\section{B. Kerangka Teoretik}

Menurut Syahrial Bakhtiar (2015: 8) Gerak dasar merupakan kemampuan dasar yang sangat penting bagi pola gerek yang telah komplek. Sedangkan menurut.Amaung Ma'mun dan Yudha M. Syahputra (2000: 20) Kemampuan gerak dasar merupakan yang bisa siswa lakukan guru meningkatkan kualitas hidup. Arti yang sederhana dapat ditafsirkan bahwa motor ability (gerak dasar ) adalah kemampuan yang umum seseorang untuk bergerak. Secara lebih spesifik mengenai pengertian motorability adalah kapasitas sesorang untuk dapat melakukan bermacam-macam gerakan yang mencerahkan gerakan yang memerlukan keberanian dalam olahraga Nurhasan,(2004:63).

Gerak dasar merupakan keterampilan yang melibatkan otak besar kekuatan otot yang melibatkan lengan dan kaki yang digunakan untuk mencapai sebuah latihan atau tujuan gerakan, seperti melempar sebuah bola, melompat, tau meloncat melewati gerakan air, atau menjaga keseimbangan. Gerak dasar dikenal juga sebagai motorik dasar.Motorik halus gerakan yang melibatkan otot kecil pada tangan, seperti menulis. Gerak dasar merupakan dasar untuk mempelajari dan mengembangkan berbagai keterampilan teknik dalam berolahraga dan aktivitas fisik seumur hidup. Dengan demikian, jika kompetensi gerak dasar anak tidk dikembangkan, mereka tidak berhasil menggunakan berbagai keterampilan olahraga dan permainan usia kanak-kanak.

\section{Gerak Lokomotor}

Samsudin (2008: 20) pada dasarnya gerakan dapat di klarifikasikan ke dalam lokomotor, non lokomotor dan manipulatif. Ketiga klasifikasi tersebut merupakan 
gerakan yang mendasari aktivitas fisik yang lebih kompleks yang lebih kompleks seperti yang banyak terlihat di dalam kegiatan berolahraga maupun dalam bermain seperti yang di sampaikan oleh David Galluhe (2006: 187) keterampilan motorik dapat yaitu: (1) Lokomotor: berjalan, berlari, melompat, (2) Kontrol objek: melempar, , menangkap, menendang, dan (3) Keseimbangan dan stabilitas. Salah satunya yaitu gerak dasar lokomotor di artikan sebagai gerakan atau keterampilan memindahkan tubuh dari satu temtap ke tempat lainnya untuk mengangkat tubuh ke atas.

Gerak dasar lokomotor merupakan dasar macam-macam ketrampilam yang sangat perlu adanya bimbingan, Latihan dan pengembangan agar anak-anak dapat melaksanakan dapat dengan baik dan benar, sebagian gerak dasar lokomotor berkembang sebagai hasil dari beberapa tahap. Proses terbentuknya gerak tidak terjadi secara otomatis, tetapi merupakan akumulasi dari proses belajar dan berlatih, yitu dengan cara memahami gerakan dan melakukan gerakan berulang-ulang yang disertai dengan kesadaran gerakan yang dilakukan.

Gerak Lokomotor ini memindahkan tubuh dario satu tempat ke tempat yang lain. Macam gerak lokomotor, yaitu: lari, lompt, loncat, lepaing, jingkat, menderap, sliding, skiping, rolling, dan memanjat.

a. Berjalan

Berjalan adalah aktivitas gerak memindahkan tubuh dari satu tempat ke tempat yang lian. Pada sat kaki melakukan pergantian langkah salah satu kaki siap menumpuh pada dasar pijakan. Dengan konsep di atas, berjalan dapat dilakukan dengan kaki, dengan tangan, dengan kaki tangan, dengan tubuh; demikian juga arahnya, ke depan dan ke belakang, ke samping kiri dan kanan dalam hal usaha, bisa cepat, lambat, keras perlahan, terhenti-henti, berkelanjutan; mintasi atau melangkahi alat.dan sebagai berikut.

b. Berlari

Berlari adalah aktivits memindahkan tubuh dari satu ke tempat ruang lain dengan menggunakan satu kaki, melakukan pergantian langkah badan dalam keadaan melayang di udara. Aplikasi konsep-konsep di atas, sesuai dengan tema berlari.

c. Berjingkat

Berjingkat adalah aktivitas memindahkan tubuh dari satu tempat ke tempat yang lain, pada saat kaki, menumpu dan mendarat menggunakan satu kaki, sedangkan satu kaki yang lain di tekuk pada bagian lutut sehingga tidak menyentuh tanah, keterampilan berjingkat salah sering digunakan dalam kehidupan sehari-hari juga sering digunakan dalam aktivitas motorik pada beberapa cabang olahraga seperti lompat jangkit, sepak bola, bola voli dan bola basket.

d. Meloncat

Meloncat adalah gerakan memindhkah tubuh dengan menggunakan dua atau satu kaki tumpu dari satu ketinggian dan mendarat tidak harus menggunakan kaki.

e. Menderap

Menderap atau mencongkang adalah gerakan berjalan dipadukan dengan lompat (leaping), arah dapat ke depan maupun ke belakang. Gerakan ini seperti 
kuda pada saat berlari kencang (menderap), tetapi hanya dilakukan dengan menggunakan dua kaki.

f. Merayap

Merayap adalah gerakan yang dilakukan dengan posisi tubuh telungkup di atas permukaan, tangan dan kaki kiri atau kanan digerakan maju secara bersamasama, kemudian kaki mendorong tubuh ke depan, dan kepal sedikit di angkat untuk melihat ke depan.

g. Memanjat

Memanjat adalah gerakan ke atas atau ke bawah dengan menggunakan kedua tangan dan kaki.Biasanya anggota tubuh bagian atas alat kontrol utama agar tidak jatuh.

\section{Permainan Tradisional}

Menurut Jarahnitra dalam Eus, (2016:65) bahwa permaian tradisional rakyat merupakan hasil budaya yang besar nilainya bagi anak-anak-anak dalam rangka berfantasi, berkreasi, berilahraga yang sekaligus sebagai sarana berlatih untuk hidup bermasyarakat, keterampilan, kesopanan, serta ketangkasan. Dharmanulya dalam Sigawati dkk, (2007:34) menyatakan bahwa permainan tradisonal merupakan saranan untuk mengenalkan anak-anak pada nilai budaya norma-norma sosial yang diperlukan untuk mengadakan hubungan atau kontak sosial dan memainkan peran yang sesuai dengan kedudukan sosial dalam masyarakat.

Permainan tradisional pada dasarnya di pengaruhi oleh kebudayaan setempat, sehingga permainan tradisonal dapat mengalami perubahan baik berupa pergantian, penambahan maupun pengurangan sesuai dengan kondisi daerah setempat. Jadi permainan tradisional pada umumnya masih memiliki persamaan/kemiripan dalam cara memainkannya meskipun nama permainannya berbeda.

Manfaat permainan tradisonal memiliki peran penting dalam segala aspek bagi para pemainnya. Manfaat yang ditimbulkan dari permainan tradisonal sangatlah beragam. Menurut subagiyo dalam Mulyani, (2016: 49-52) menyebutkan bahwa terdapat beberapa manfaat dari permainan tradisonal, antara lain:

a. Anak menjadi kreatif. Permainan tradisonal biasanya dibuat langsung oleh para pemainnya. Mereka menggunakan barang, benda atau tumbuhan yang ada di sekitar. Hal ini mendorong mereka untuk lebih kreatif menciptakan alatalat permainan.

b. Bisa digunakan sebagai terapi terhadap anak. Saat bermain anak-anak akan melepaskan emosinya. Mereka akan berteriak, tertawa, dan bergerak mengikuti susasana permainan.

c. Mengembangkan kecerdasan intelektual anak. Permainan tradisional membantu anak untuk mengembangkan kecerdasan intelektualnya. Sebab perminan tersebut menggali wawasan anak terhadap beragam pengetahuan.

d. Mengembangkan kecerdasan emosi antar personal anak. Hampir semua permainan tradisonal dilakukan secara berkelompok. Dengan berkelompok, anakakan mengasah emosinya sehingga timbul toleransi, empati terhadap orang lain, nyaman dan terbiasa dalam kelompok. 


\section{Permainan Hadang}

Husni (1991:447) menjelaskan permainan hadang adalah suatu permainan yang tradisonal yang terdapat di berbagai provinsi seperti di pulau jawa disebut gobok sodor, jakarta disebut galah asin, Sumatra Utara disebut margalah, sulawesi selatan disebut Massallo dan dibengkulu disebut hadang lebih lanjut lagi Wardani (2002:75) menjelaskan bahwa permainan galah/hadang dilakukan oleh anak laki-laki atau perempuan berusia 10-16 tahun dalam permainan ini mengutamakan kerjasama dalam tim sehingga memperoleh kemenangan dalam permainanya. Kerjasama tim diperlukan untuk melumpuhkan ataupun mengajalahkan teman lawan mainnya, sehingga dapat memperoleh kemenangan dalam pertandingan hadang.

Menurut Irwanto (2003:73) permainan tradisonal hadang adalah permainan olahraga tradisional yang tidak mempergunakan alat apapun sebagaimana permainan tradisional sebelumnya.Oalhraga tradisonal hadang dimainkan secara beregu, baik putra maupun putrid.Jumlah anggota regu sebanyak 8 orang dari 5 orang sebagai pemain inti dan 3 orang selebihnya sebagai pemain cadangan.Permainan tradisonal hadang bertujuan untuk mengetahui tingkat kebugaran jasmani seseorang untuk memperoleh hasil yang maksimal dalam permainan hadang tradisonal.

Permainan tradisional hadang merupakan permainan tradisional Indonesia dengan nama-nama atau sebutan yang beragam, adapun permainan hadang ini di Maluku Utara disebut dengan permainan sem.Sem, biasanya dipaling ramai dilakukan saat bulan ramadhan.

Nilai-nilai yang terkandung dalam permainan tradisonal gobag sodor didapatkan melalui ekspresi anak tentang dianggap penting, dibutuhkan dan harus dilakukan dalam permainan tersebut. Nialai-nilai dalam permainan tradisional gobag sodor adalah sebagai berikut: yang pertama dalam aspek jasmani yang meliputi nilai kesehatan dan kelincahan. Kedua aspek psikologis yang meliputi nilai kejujuran dan sportivitas, kepemimpinan, pengaturan strategi, kegembiraan, spritualisme, perjuanagn.Aspek ketiga yaiitu sosial yang meliputi nilai sosial skill, kerjasama dan kekompakan Siagawati dkk, (2017).

Menurut Dahrmamulya (1992-1993) permainan tradisional gobag sodor merupakan permainan yang kekompakan, maka kekompakan tersebut harus kompak, masing-masing anggota harus bekerja sama, saling membantu, dan saling mengenal tugas dan kewajibannya. Apabila ada yang tledor, kurang waspada maka akan dimarahi oleh anggota kelompoknya. Unsur siakap tolong menolong, saling membantu, mengenal kebutuhan bersama dapat tertanam melalui permainan ini. Permainan ini juga memiliki berbagai peraturan bermain, maka para pelaku akan selalu terlatih untuk menataati peraturan yang ada, sehingga mengetahui dampak menataati peraturan dan tidak menatati peraturan. Latihan keberanian (kendel) dan bandel juga terbina melaui permainan ini.

Manfaat permainan tradisional gobak sodor / hadang ini lainnya adalah melatih keterampilan fisik agar menjadi kuat, sehat dan capak Ariani dalm Siagawati dkk, (2006) Menurut Ketua Kommans Perlinduungan Anak, Seto Mulyadi, tingkat kecerdasan anak dapat dipupuk melalui tindak serta aktivitas anak dalam memainkan permainan tradisional dalam junianto, (2009). Anak-anak juga dituntut untuk selalu 
aktif secara fisik, maka secara fisik organ-organ tubuh anak akan senantiasa terbiasa untuk bergerak, Sealain itu anak-anak terlatih untuk bersikap gentle, jujur, serta mau dan berani mengakui kesalahan dan kekalahan mereka Junianto, (2009).

Berdasarkan uraian diatas maka permainan hadang tersebut dilakukan di PAUD Negeri 1 Pembina Kota Ternate dengan memusatkan pada kegiatan gerak dasar lokomotor berpindah tempat dan berlari.

\section{Metode Penelitian}

Penelitian ini dilakukan di PAUD Negeri Pembina 1 Kota Ternate yang berada di kel. Dufa-dufa Kecamatan Kota Ternate Utara. Waktu penelitian di laknasakan selama 4 bulan yang di mulai pada Februari 2021 sampai pada Mei 2021, Penelitian ini di laksanakan sejak dari waktu untuk perencanaan sampai penulisan laporan hasil penelitian.

Metode penelitian yang digunakan dalam penelitian ini adalah metode deskriptif. Menurut Whintney 1960 dalam Nazir (2009) metode deskriptif adalah pencarian fakta dengan interpretasi yang tepat. Penelitian deskriptif mempelajari masalah-masalah dalam masyarakat serta tata cara yang berlaku dalam masyarakat serta situasi-situasi tertentu, termasuk tentang hubungan, kegiatan-kegiatan, sikap, pandangan, serta proses yang sedang berlangsung dan pengaruh-pengaruh dari suatu fenomena.

Tabel 1 Indikator Penelitian

\begin{tabular}{|c|c|}
\hline Variabel & Indikator \\
\hline \multirow{3}{*}{$\begin{array}{c}\text { Gerak Lokomotor Pada } \\
\text { Permainan Hadang }\end{array}$} & Berpindah Tempat \\
\cline { 2 - 2 } & Berlari \\
\cline { 2 - 2 } & Melompat \\
\hline
\end{tabular}

Teknik pegumpulan data merupakan langkah yang paling utama dalam proses penelitian, karena tujuan utama dari penelitian adalah pengumpulan data mana yang paling tepat, sehingga benar-benar didapat data yang valid dan realiable.

Terdapat dua hal utama yang mempengaruhi kualitas data hasil penelitian yaitu, kualitas instrumen penelitian dan kualitas pengumpulan data. Kualitas instrumen penelitian berkenaan dengan validitas dan reabilitas instrumen dan kualitas pengumpulan data berkenaan dengan ketepatan cara-cara yang digunakan untuk mengumpulkan data.

\section{Analisis Gerak Lokomotor Dalam Permainan Tradisonal Hadang Kelas B1 Usia 5-6 Tahun}

Penelitian ini dilakukan di PAUD Negeri Pembina 1 kota Ternate dengan Judul Analisis Gerak Lokomotor Dalam Permainan Tradisonal Hadang Kelas B1 Usia 5-6 Tahun di PAUDNegeri Pembina 1 Kota Ternate. 
Hasil wawancara, observasi, dan dokumentasi yang peneliti paparkan kemudian peneliti analisis dengan mengunakan beberapa indikator gerak lokomotor yaitu 1). Berpindah-pindah tempat 2). Berlari tanpa jatuh.

Berdasarkan hasil penelitian yang peneliti dapatkan yaitu subjek 4 orang peserta didik Kelompok B, sebagai berikut :

Tabel 2 Daftar Peserta didik

\begin{tabular}{|l|l|}
\hline Nama & Kelas \\
\hline M. Alfatih Ismail & B \\
\hline Ghafir Kharie & B \\
\hline Zaky & B \\
\hline M. Gabriel Mahmud & B \\
\hline
\end{tabular}

\section{Gerak Lokomotor Berpindah Tempat}

Pertama-tama ketika permainan hadang dimulai AI mulai bersiap-siap untuk memasuki garis yang ada.Terlihat AI berpindah-pindah tempat berulang-ulang dan mencari posisi yang luang agar bisa masuk kedalam lini pertahanan bidang dari lawan main. Kegiatan berpindah tempat selanjutnya dilakukan pada bidang garis kedua.AI melakukan gerakan maju mundur untuk menggelabui lawan mainnya agar terkecoh dan mencari kesempatan untuk memasuki bidang garis ketiga. Namun pada saat gerakan berpindah tempat AI terhenti saat berlari karena di hadang oleh tim lawan yang aktif.

Kegiatan lokomotor berpindah tempat selanjutnya dilakukan oleh GK saat berman hadang, GK melakukan gerakan berpindah tempat saat memulai atau start bermain sebagai tim lawan berjaga mempertahankan benteng hadangnya, dia bergerak kekiri dan kekanan sambil merentangkan tangannya agar bisa menyentuh tubuh lawan, setelah itu gerakan selanjutnya yang dilakukan GK adalah berbalik badan dan mengikuti garis lurus ruang hadang sambil berpindah-pindah tempat dan merentangkan tangannya. Gerakan berpindah-pindah tempat dilakukan terus menerus dengan aktif dan penuh semangat agar dapat mengalahkan lawan man dengan cara menyentuh tubuh lawan.

Selanjutnya peserta didik $\mathrm{Z}$ bermain hadang merupakan anggota tim lawan jaga saat kegiatan bermain di mulai $\mathrm{Z}$ menjaga tim lawan di garis bidang tengah, pada saat itu $\mathrm{Z}$ berpindah-pindah tempat untuk menghadang tim lawan agar tidak memasuki bidang garisselanjutnya ketika $\mathrm{Z}$ melakukan gerakan berpindah tempat berung-ulang. Gerakan yang muncul adalah gerakkan berpindah-pindah tempat berulang-ulang kali dseperti maju mundur dan gerakan kekiri dan kekanan sambil menunjukkan gerakan menangkap lawan. Karenatim lawannya ingin berusaha memasuki garis bidang. $\mathrm{Z}$ mulai bersiap-siap menghadang tim lawan agar tubuh tim lawan disentuh oleh yang mau berusaha memasuki garis bidang di titik selanjutnya.

Adapun juga peserta didik yang paling aktif MGM pada saat melakukan permainan hadang MGM berpindah-pindah tempat memasuki bidang garisnya, kemudian MGM sudah mamasuki bidang garis di depan tim lawan jaga setelah itu MGM berusaha berpindah tempat kekiri dan kekanan untuk memasuki garis 
selanjutnya karena di hadang oleh tim lawan jaga tetapi MGM berhasil ke garis finisnya. Kemudian MGM kembali berpindah tempat untuk kembali ke tempat sebelumnya, setelah itu MGM terlihat lelah dan duduk lalu berdiri lagi melanjutkan permainan dengan semangat.

Berdasarkan hasil observasi yang dilakukan peneliti terkait Perkembangan dan kemampuan gerak dasar lokomotor anak pada gerakan berpindah tempat dengan permaninan hadang di PAUD Pembina 1 Kota Ternate telah mengembangkan keaktifan anak dalam bergerak khususnya gerakan lokomotor berpindah tempat, tidak ada anak yang tidak aktif selama kegiatan berman.Dari keempat peserta didik, semuanya melakukan gerakan berpindah tempat dengan cara maju mundur, bergerak melangkah kekiri dan kekanan mengikuti garis bidang hadang.

\section{Gerak Lokomotor Berlari}

Pertama-tama peserta didik AL mulai bersiap-siap untuk memasuki bidang garis, setelah itu AL terlihat sedang berlari sekencang mungkin untuk bisa sampai ke bidang garis selanjutnya pada saat AL berlari tiba-tiba AL di hadang oleh tim lawan jaga dan AL sudah tersentuh oleh dua tim lawan jaga. Kemudian AL terjatuh bersamaan dengan tim lawan jaga dan mereka berusaha bangun kembali disitu AL sudah kalah dan AL sudah tidak bisa lagi berlari ke bidang garis selanjutnya dalam permanan hadang tersebut, lalu AL kembali berlari ke tempat sebelumnya untuk mempertahankan lini bidang hadang yang dia jaga.

Peserta didik selanjutnya GK dalam permainan hadang GK adalah anggota tim jaga lawan, saat GK menjaga lawanGK berlaripada saat bermain. GK berusahamenjaga tim lawan untuk memasuki bidang garis dan GK berusaha untuk menyentuh tubuh lawannya dengan berlari mengikuti lawan mainnya agar tidak memasuki garis pertama sampai garis selanjutnya. GK tidak melihat tim lawan saat berlari memasuki bidang garis pertama, GK berlari ke tempat bidang garis ke dua agar menjaga tim lawannya. Tetapi tidak berhasil menangkap tim lawan, GK mencoba berlari ke garis ke kedua sampai dapat menyentuh tubuh lawan mainnya. GK berlari mengikuti dan menjaga lawan main yang lain agar tidak berhasil masuk ke bidang hadang selanjutnya.

Selanjutnya peserta didik yang paling aktif adalah MGM sedang bersiap-siap untuk memasuki bidang garis, kemudian saat MGM sudah mamasuki bidang garis pertama MGM berlari tidak berhenti sepanjang garis bidang hadang dengan tujuan dapat menghentikkan gerak lawan. Dengan keaktifannya berlari, membuat salah satu anggota lawan berhasil berhenti bermain.capainnya tersbut tidak menghentikkannya untuk terus berlari melakukan gerakan hadang ke tim lawanya. Gerakan berlari yang muncul adalah gerakan berlari sepanjang garis hadang.

Berdasarkan hasil obersvasi yang di lakukan oleh peneliti terkait dengan kemampuan dan perkembangkan gerak dasar pada anak di PAUD Negeri Pemnina 1 Kota Ternate sangat aktif dalam melakukan gerakan lokomotor berlari selama kegiatan berman hadang dilakukan, gerakan lari yang muncul adalah ketika anak mulai melakukan permainan dengan cara memasuki setiap bidang hadang dan saat peserta didik bertugas sebaga tim lawan menjaga bidangnya agar tidak dimasuki oleh anggota tim lawannya. 


\section{Gerak Lokomotor Melompat}

Adapun juga peserta didik MGM pada saat melakukan permainan hadang MGM bersiap-siap untuk memasuki garisnya, MGM sedang melompat-lompat 6 kali di depan tim lawan jaga setelah itu MGM berusaha berlari dan untuk memasuki garis selanjutnya karena di hadang oleh tim lawan jaga, tetapi MGM berhasil ke garis finisnya. Kemudian MGM kembali melompat-lompat 3 kali untuk kembali ke tempat sebelumnya.

Selanjutnya peserta didik GK adalah tim lawan jaga dalam permainan hadang saat GK melakukkan persiapan untuk berjaga-jaga agar tim lawan tidak memasuki di bidang garis,pada saat itu GK terlihat melompat-lompat pada saat bermain, ketika GK sudah melakukan persiapan untuk menghadang tim lawannya GK membalikkan badan agar melihat tim lawan apakah tim lawan berada di belakang atau tidak, saat itu GK menuju di bidang garis ke dua agar GK berusaha menyentuh tubuh tim lawannya, setelah itu GK kembali ke tempat bidang garis pertama terlihat GK melompat lagi lompatannya satu kali kemudian GK kembali lagi berjalan pelan-pelan menuju ke tim lawan disitu GK berhasil menyentuh tubuh tim lawan tersebut.

Hasil observasi yang di lakukan oleh peneliti terkait dengan Perkembangan dan kemampuan gerak dasar anak di PAUD Pembina 1 Kota Ternate kemampuan gerakakan dasar melompat dan anak sangat aktif sekali pada melakukan gerakan lompat sebagai ancang-ancang untuk memulai permainan dan memasuki bidang hadang.

\section{Data Wawancara}

\section{Berpindah Tempat}

Hasil wawancara oleh tenaga pendidik PAUD Negeri Pembina 1 Kota Ternate terkat berpindah tempat dengan uraian reduksi wawancara sebagai berikut :

Hasil dari wawancara oleh ibu AT:

"Ya karena aktivitas yang menggunakan otot pada anak adapun di antaranya keterampilan no-lokomotorik juga, gerak lokomotor adapun juga gerakan manipulative, karena anak memiliki aktivitas memindahkan tubuh ke tempat lainnya. Misalnya ada anak yang mendorong pada saat dalam permainan hadang."

Hal ini juga dikatakan oleh ibu I:

"Ya kelincahan pada saat bermain untuk meningkatkan kelincahan anak secara perekembangan mereka karena salah satu kemampuan motorik anak ketika pada saat bermain anak mengubah arah dan posisi tubuh dengan cepat dan tepat disaat bermain tubuh anak bergerak pada suatu titik ke titik lain dalam melakukan suatu keterampilanmotorik kasar pada aspek kelincahan pada anak. Karena dapat melakukan kegiatan bermain hadang lebih mudah."

"Oleh karena itu sebuah permainan tradisional hadang di PAUD B1 Pembina 1 Kota Ternate, tingkat kelincahan pada anak untuk guru harus memodifikasi melalui permainan hadang supaya mengoptimalkan lagi dan melatih kelincahan pada peserta didik." 
Hasil wawancara dari pendidik AT di atas maka disimpulkan bahwa dalam bermain hadang dapat merangsang anak unutk melakukan gerak dasar lokomotor yaitu berpindah tempat, gerakan ini muncul saat anggota tim lawan mencoba menyentuh/mendorong peserta yang bergiliran main masuk kedalam bidang hadang.

\section{Berlari}

Berdasarkan hasil observasi yang dilakukan peneliti terkait dengan melihat kemampuan motorik anak dalam proses mampu berlari t bermain dalam permainan tradisional hadang peneliti disini melihat ibu I dan ibu AT saat melatih bagaimana cara anak berlari dengan benar karena peneliti melihat ada kendala-kendala terhadap anak yang masih belum fokus pada permainan hadang jadi bagaimana cara mengatur anak dengan baik dalam permainan tradisonal hadang.

Berdasarkan hasil wawaancara dengan ibu I:

"guru punya gaya tersendiri mengatur anak-anak ini agar di latih cara berlari ......nah disitu ada beberapa anak tidak fokus dalam bermain karena anak sudah berlari kesana kemari, anak-anak setelah dilatih bermain hadang, mereka antusias deng semangat untuk berlari dalam sem"

Hasil wawancara ibu AT tentang indicator berlari pada bermain tradisional hadang sebagai berikut :

"Ya kemampuan kecepatan terhadap anak di PAUD Negeri Pembina 1 Kota Ternate, kemampuan ini tergantung juga kan dari organ perasa dalam mengatur saat permainan hadang ini mulai, bisa dialng juga kecepatan lari -lari atau gerak dalam bermain hadang, ketika anak. Karena harus memberikan stimulasi pada anak.dan sudah dikatakn juga pada ibu I kita harus melatih anak pada saat permainan tradisosnal hadang ini."

Kesimpulan dari 2 orang guru yang di atas bahwa gerakan lokomotor berlari dalam permainan tradisinonal ini pada anak dan dapat berkembang dengan sangat baik.Sehingga dapat disimpulkan dari hasil bahwa kemampuan gerak berlari pada anak rata-rata sudah berkembang dengan baik pada saat peserta didik di latih oleh guru, adapun juga peserta didik yang sedang start bermain maupun yang sedang menjaga bidang hadang sama-sama melakukan gerakan lokomotor berlari untuk mengkap/menyentuh lawan atau berlari menghindari lawan.

Hasil dari observasi yang gerakan lokomotor terhadap anak untuk distimulasi dengan berbagai macam bermain, salah satunya dalam permainan tradisonal hadang akan mengembangkan kemampuan berlari yang mendukung ketangkasan, kecepatan, dan kelincahann sehingga tumbuh kembang anak menjadi lebih optimal, nah disini peneliti melihat anak yang pelaksanaannya, sehingga perlu dilakukan permainan tradisional hadang sebagian besar peneliti melihat tingkat kemampuan gerak lokomotor berlari peserta didik kelompok B1 Di PAUD Pembina 1 Kota Ternate sangat baik.

\section{Melompat}

Berdasarkan hasil wawancara dengan ibu AT tentang gerakan dasar lokomotor pada permainan tradisional hadang adalah sebagai berikut :

Hasil wawancara dari ibu AT:

"Perkembangan dan kemampuan gerak dasar anak di PAUD Pembina 1 Kota

Ternate sudah terbilang sangat bagus karena kemampuan gerakakan dasar 
yang mereka lakukan disini ada beberapa gerakan yaitu berlari, melompat pada saat bermain pertama awal bermain anak mulai berjaga-jaga dan menunggu serangan yang masuk di dalam garis agar anak bisa lolos dalam bermain permainan tradisonal hadang tersebut, adapun jika ada anak yang melompatlompat dalam permainannya."

Indikator gerakan dasarlokomotor melompat pada kegiatan bermain tradisional hadang pada ibu I sebagai berikut:

"melompat dalam permainan hadang,untuk menjaga keseimbangan tanpa jatuh adapun juga kendala-kendala tersebut akan dikut dengan dunia anak tersendiri kaerna jika guru fokus ke pandangan lain atau ke anak lain."

Hasil dari wawancarayang di lakukan oleh peneliti terkait gerakan lokomotor melompat pada kegiatan bermain tradisional hadang adanya keaktifan anak dalam melakukan gerakan lokomotor melompat pada saat hendak masuk pada garis start dan saat menghadang lawan main. Dengan cara melompat-lompat perkembangan motorik kasar lokomotor berkembang denganbaikpada saatsaat anak lain sudah fokus pada permainnya guru juga harus melatih pada anak sebagai mungkin.Supaya perkembangan anak lebih optimal lagi.

Perkembangan koordinasi gerakan otot-otot kasar yang dilakukan pada peserta didik dan kemampuan gerak dasar peserta didk di PAUD Pembina 1 Kota Ternate berjalan dengan efektif karena kemampuan gerakakan dasar dalam permainan hadang dari kegiatan ini yang mereka lakukan disini ada beberapa gerakan yaitu berpindah tempat,berlari, dan melompat.Koordinasi adalah kemampuan otot tubuh dalam mengontrol gerak dengan tepat agar mencapai tugas fisik tertentu. Pendapat ini diperjelas oleh Suharno (Sridadi, 2011):4),koordinasi adalah kemampuan seseorng untuk merangkai beberapa unsur gerak menjadi suatu gerakan yang selaras sesuai dengan tujuannya kemampuan menampilkan tugas gerak dengan luwes dan akurat yang seringkali melibatkan perasaan dan seringkaian koordinasi otot yang mempengaruhi gerakan.

Gerakan berpindah tempat dalam permainan tradisonal hadang pada peserta didik, perkembangan dan kemampuan gerak berpindah tempat dimana bagian tubuh tertentu bergerak atau berpindah tempat misalnya,jalan,berlari dan loncat.Saat melakukan gerakan maju mundur untuk menggelabui lawan mainnya agar tim lawan mencari kesempatan untuk memasuki bidang garis pada saat gerakan berpindah tempat.

Berlari melompat seimbang tanpa jatuh perkembangan dankemampuan motorik anak dalam proses mampu berlari sambil melompat dengan seimbang tanpa jatuh pada saat bermain dalam permainan tradisional hadang peneliti disini melihat beberapa anak juga dengan keseimbangannya sudah optimal saat bermain.Gerakan berlari merupakan perkembangan dari gerakan dasar yaitu gerakan berjalan, gerakan dasar anggota tubuh berlari hampir sama dengan berlari, Sumantri,Sedangkan meloncat mula-mula tampak atau bisa terbentuk dari gerakan berjalan dari tempat yang agak tinggi ke tempat yang agak rendah, misalnya saat menuruni tangga atau turun dari bangku yang pendek. Sumantri, (2005:75).

Berlari terhadap peserta didik untuk distimulasi dengan berbagai macam bermain, salah satunya dalam permainan tradisonal hadang untuk mengembangkan kemampuan berlari, terhadap pesrta didikdalam kegiatan permainan trsdisional hadang, 
sebagian besar melihat tingkat berlari dan kekompakan sudah optimal secara bersamaan di kelompok B1 Di PAUD Pembina 1 Kota ternate. Hursono Wira Indra Satya, (2006: 17) menjelaskan ke (agility) adalah kemampuan untuk mengubah arah dan posisi tubuhnya.

Gerak dasar melompat pada peserta didik dalam permanan tradisonal hadang di PAUD Negeri Pembina 1 Kota Ternate Lompat merupakan salah satu nomor dalam cabang olahraga atletik yan mempunyai peran penting untuk menunjang perkembangan dan pertumbuhan peserta didik.Lompat yang digunakan dalam cabang olahraga atletik, yaitu melakukan tolakan dengan 1 kaki. Aip Syarifuddin (1996:90).

Yudha M. Saputra (2005: 46) berpendapat lompat adalah gerakan dasar yang terjadi ketika tubuh diangkat ke udara karena tekanan yang berasal dari satu atau ke dua tungkai dan tubuh mendarat menggunakan satu atau dua kaki. Gerak lompat dapat di bagi menjadi beberapa cara, misalnya hopping (meloncat) adalah bentuk dari melompat karena adanya daya dorong yang berasal dari tungkai dan mendarat dari kaki tungkai gerak ini disebut leaping (melompat).

Berdasarkan data hasil wawancara yang diperoleh peneliti terdapat 2 indikator terdisi dari 1) Gerak Lokomotor. 2) Permainan Tradisional Hadang yang digunakan. 2 indikator di atas peneliti membuat 10 pertanyaan yaitu: 1) Apakah Permainan Tradisional Hadang ini membuat anak-anak aktif? 2) Gerak lokomotor apa yang ibu ketahui dalam bermain hadang? 3) Dari seluruh peserta apakah ada peserta yang paling aktif dalam bermain hadang? 4) Bagaimana perkembangan peserta didik pada saat bermain hadang? 5) Apa saja kendala-kendala yang dihadapi oleh guru oleh guru dalam mengembangkan gerak lokomotor? 6) Bagaimana perkembangan kemampuan gerak dasar pada peserta didik di kelompok B1 di PAUD Negeri Pembina 1 Kota Ternate? 7) Bagaimana perkembangan fisik lokomotor dalam permainan tradisional hadang? 8) Bagaimana gerak lokomotor berpindah tempat pada anak? 9) Bagaimana gerakan lokomotor berlari pada anak saat bermain hadang? 10) Bagaimana gerakkan lokomotor melompat pada saat sedang bermain hadang?

Berdasrkan 10 pertanyaan di atas 7 pertanyaan yang membahas tentang Gerak Lokootor dan 3 Permainan tradisional hadang.

\section{E. Simpulan}

Berdasarkan hasil yang dilakukan oleh peneliti ini dapat disimpulkan bahwa dalam permainan tradisonal hadang di PAUD Negeri Pembina 1 Kota Ternatesecara keseluruhan telah dilaksanakan dengaan perkembangann gerak lokomotor sangat baik dalam permainan tradisonal ini, perkembangan fisik motorik sudah mulai berkembang dan mampu meningkatkan kemampuan gerak pada anak, yaitu gerak berpindah tepat, berlari, melompat untuk melatih otot-otot kaki tangan dan koordinasi mata dan beberapa guru sudah mualai berkomunikasi atau menyampaikan dengan baik pada peserta saat melakukan bermain di lapangan tersebut. 


\section{DAFTAR PUSTAKA}

Aip Syarifuddin (1996), Belajar Aktif Pendidikan Jasmani dan Kesehatan, untuk Sekolah dasar kelas I sampai kelas IV, Jakarta, Penerbit PT. Gramedia.

Amung Ma'mun dan Yudha M. Saputra. (2000). Perkembangan Gerak dan Belajar Gerak. Jakarta: Departemen Pendidikan dan Kebudayaan

Ardiwinata A, dkk. (2006). Kumpulan Permainan Rakyat Olahraga Tradisional. Jakarta

Bakhtiar, Syahrial. 2015. Merancang Pembelajaran Gerak Dasar Anak. Padang: UNP Press.

Dani Nurdiansyah. 2018 Pengaruh Permainan Tradisonal Hadang Terhadap Agilty Jurnal. Universitas STKIP Muhammaddiyah Kuningan.

Emi Supadmi. 2015 Pengembangan model permainan Gobak sodor untuk pebelajaran gerak lari pada anak kelas 1 SD 2 karang. Skripsi Universitas Negeri Semarang.

Hemawan 2018. Peningkatan Hasil Belajar Permainan Tradisional Pada Tema 3 Subtema 2 Siswa Kelas IV SDN. Skripsi. Universitas Sanata Dharma Yogyakarta.

Janari Juli. 2012. Permainan Tradisional Dalam Bentuk Karakter Anak Usia Dini jurnal vol.1. Universitas Islam Negeri Sulatn.

Meti Artika 2020. Upaya Penerapan Permainan Tradisional Dalam Menggembangkan Motorik Kasar Anak Kelas AI skripsi Universitas Islam Negeri Intan Lampung.

MS Sumantri. (2005). Pengembangan Keterampilan Motorik Anak Usia Dini. Jakarta: Dinas Pendidikan.

Nurhasan.(2005). Aktivitas Kebugaran. Jakarta: Depdiknas.

Partavi, S. 2013. Effect Of 7 Weeks Of Rope-Jump Training on Cardiovascular Endurance, Speed and Agility In Middle School Student Boys. Sport Science 6 (2013) 2: 40-43

Rizali 2015. Pengaruh Latihan Hadang Terhadap Kelincahan Kecepatan Lari Jurnal Vol.1.5.no 1.

Yuliangga Nanda Hanief 2015. Membentuk Gerak Dasar Pada Siswa Melalui Permainan Tradisional Jurna vol.1 no $l$.

Sujiono, Bambang. 2008. Hakekat Perkembangan Motorik Halus Anak.Dalamhttp://melyloelhbox.blogspot/2013/05/hakikat-perkembanganmotorik-halus-anak.html.Diakses pada 7 April 2014.

Sumantri. 2005. Hakekat Perkembangan Motorik Halus Anak. Dalamhttp://melyloelhbox.blogspot/2013/05/hakikat-perkembangan-motorikhalus-anak.html.Diakses pada 7 April 2014 .

Yudha M. Saputra dan Rudiyanto, 2005. Pembeljaran Koperatif Untuk Meningkatkan Keterampilan Anak Tk. Jakarta: DepDiknas, Dikit DirektoratP2TK2PT. 